\title{
Greg Nightingale
}

University of Western Ontario, London, ON, Canada

\section{A BENJAMINIAN EXPLORATION OF LIBRARY AS PLACE (Paper)}

\begin{abstract}
This paper presents the case for using Walter Benjamin's study of modernity, The Arcades Project, as theoretical lens through which to consider both the public library as a place and library as place research more generally. The public library, at once a "past become space" and a contemporary institution, is a site of multiple dialectics and transformative thresholds.
\end{abstract}

This study is a theoretical exploration of Walter Benjamin's Passagen-Werk (The Arcades Project) as an historical lens with which to conduct a contemporary critique of library as place. This approach is based on the concurrent social and cultural development of shopping arcades and public libraries. The modern public library, by embodying one potentiality of modernity, stands as a counterpart to Benjamin's symbolic arcade, which developed along a divergent path. It follows, then, that like the arcade, the modern public library contains within itself both a critique of modernity and a revolutionary potentiality, in its spaces, collections, and modes of circulation. My goal is to use Benjamin's historical dialectical approach to critique contemporary notions related to our understanding of the public library as a place. This critical method stands in contrast to other "library as place" research, which tends to describe the physical and historical characteristics of library spaces (e.g, Russo 2008), to treat the presence of any library as "beneficial" (e.g., Tetreault 2007), or treats library as place as a given, by the mere fact the library occupies a physical site. I use Griffis' (2013) definition of "library as place" research: "the study of libraries as built environments including their cultural, geographical, and historical contexts, as well as their representative properties as social, political and informational space" (8).

I hope to advance library as place research by considering some features of contemporary public libraries, our professional collective dreams, and how the public library, like the arcade, is "a past become space" (Benjamin 1999 [1927], 871). What are the nineteenth-century dreams from which the public library collective (academics, librarians, staff, board members, patrons, community members) must awaken? How do these dreams manifest in our library spaces, in the library as a place, and in the subdiscipline of library as place? For example, Griffis (2013) states that "the library as an organization still relies on many of the same socio-spatial models of control as it did one century ago when public library building design first became standardized" (iii). In this paper, I answer a central question: To what extent are Benjamin's theories applicable to library as place? I argue that an examination of Benjamin's methods in compiling the Passagen-Werk, of his archetypal flâneur, and of the history of the arcades, contrasted with and informed by more recent literature regarding public libraries, reveals a clear progression in the design of the public library building, the dialectical tensions surrounding multiple thresholds within the library, and a new perspective on the communities that form in the library. In the end, informed by Benjamin's concept of dialectical images and his emphasis on the persistence of nineteenth-century collective dreams, I present an image of the public library as place that sustains, as the arcades did for Benjamin (1999 [1927]), "a past become space" (871) and numerous collective dreams remnant from the nineteenth century, yet also offers us and our communities the chance to "awaken". 
Benjamin's methods of research, reading, quoting, citing, composing, and endlessly revising have been covered a great deal, especially with regards to The Arcades Project with its massive, overlapping, and unfinished structure. Scholars have attempted to situate Benjamin himself within his representative archetypes (most of which he borrowed from Baudelaire) of the nineteenth century. I discuss the extent to which the archetypes of the ragpicker, allegorist, collector, student, and gambler are relevant to a Benjaminian approach to library as place research. For example, Benjamin was not, like the ragpicker, combing through sources discarded in gutters and trash heaps, literally thrown away. He was accessing materials consciously and purposely stored and preserved by la Bibliothèque nationale, perhaps the largest, most powerful, most significant library in the world at the time, which had as its central mission the construction of the modern nation-state. Many of the sources Benjamin used might have been forgotten, but they were neither rags nor refuse; they were parts of collections. In addition to his research within libraries, Benjamin's knowledge of the arcades was centered on libraries, specifically la Bibliothèque nationale and the still surviving arcades that surrounded it. The library building, the library collection, and the library's surroundings all immediately informed Benjamin's work on the arcades. Is this not an illustration - an image - of the importance of "library as place"? Yes, but only if we take his dialectical method to heart, as opposed to one that uncritically considers anything related to the physical library space as beneficial, positive, or even ideal.

The flâneur, the most persistent of the nineteenth-century archetypes adopted by Benjamin from Baudelaire, crosses many thresholds during — or, along - the course of his day. Crossing the threshold is a highly symbolic act for Benjamin, portending personal and social awakenings and transformations. The threshold is not a boundary, but rather a zone in which action takes place, akin to a rite of passage (recall that in French, arcades are passages). The arcade, at once street and house, inside and outside, exterior and interior, shrouded in myths and magic, connecting the city's neighbourhoods, commercial areas, and residential areas, offers numerous thresholds, not the least of which is the commodity that ushers in the new age of capitalism. Missac (1995), Benjamin's long-time acquaintance and translator, who helped recover the Passagen-Werk manuscript from la Bibliothèque nationale, accepts the symbolic importance of Benjamin's arcades, yet takes this thought one step further: "Hence the twentieth century, and perhaps the twenty-first, appear as extensions of the nineteenth or even earlier centuries" (177). Yet each moment contains a revolutionary potentiality if we "recognize a particular point of development as a crossroads" [S1,6]. ${ }^{i}$ In other words, "[t] he enchantments of modernity contain within them the seeds of their own disenchantment" (Gilloch 2002, 118). This was as true during Benjamin's time periods - both the one in which he lived the one about which he wrote - as it is today.

Our collective dreams manifest themselves in no doubt countless ways. I emphasize two recurring trends in the library as place literature: the public library as the "living room" of the community and the economic importance of library sites. The nineteenth-century bourgeois interiors and façades, which Benjamin was fascinated by and whose inherent repressiveness was noted by Lefebvre (1991 [1974/1984]), along with their subsequent move outside, provide a clear connection. "Streets are the dwelling place of the collective. [...] More than anywhere else, the street reveals itself in the arcade as the furnished and familiar interior of the masses" [M3a,4]. Nineteenth-century personal libraries and public parlours, as described by Arenson (2007), share many similarities with Benjamin's nineteenth-century bourgeois parlours. The public library, with its atrium and alcoves, is the nineteenth-century parlour made living room of the community, where the inside and outside are indistinguishable. In this dream state, the public library is where our nineteenth-century collective dreams dwell. Miller (2006) points out that "dwelling" is related 
to "the problem of community, the nature of metropolitan experience" (257; emphasis mine). I contend that nineteenth-century personal libraries became public through the gradual involvement of the community, yet self-perpetuating contemporary public libraries must now use the community to justify projects, rather than naturally being justified as community projects. A Benjaminian dialectical approach, by turning obstacles into thresholds and embracing the public library as a site of multiple dialectics, can bring the public library's possible self-negation to a standstill. I conclude my discussion by highlighting several examples from contemporary public libraries - such as signage, library display, the "retail" library service model, and library designthat can benefit from such an approach.

\section{Reference List:}

Arenson, Adam. "Libraries in Public before the Age of Public Libraries: Interpreting the Furnishings and Design of Athenaeums and Other 'Social Libraries,' 1800-1860." In The Library as Place: History, Community, and Culture, edited by John E. Buschman and Gloria J. Leckie, 41-60. Westport, CT: Libraries Unlimited, 2007.

Benjamin, Walter. The Arcades Project. Translated by Howard Eiland and Kevin McLaughlin. Cambridge, MA: The Belknap Press of Harvard University Press, 1999.

Gilloch, Graeme. Walter Benjamin: Critical Constellations. Cambridge, UK: Polity Press, 2002.

Griffis, Matthew R. "Space, Power and the Public Library: A Multicase Examination of the Public Library as Organization Space." Doctoral dissertation, University of Western Ontario, 2013.

Lefebvre, Henri. The Production of Space. Translated by Donald Nicholson-Smith. Oxford, UK \& Cambridge, MA: Basil Blackwell, 1991 [1974/1984].

Miller, Tyrus. "'Glass before Its Time, Premature Iron': Architecture, Temporality and Dream in Benjamin's Arcades Project." In Walter Benjamin and The Arcades Project, edited by Beatrice Hanssen, 240-258. New York: Continuum, 2006.

Missac, Pierre. Walter Benjamin's Passages. Translated by Shierry Weber Nicholsen. Cambridge, MA: The MIT Press, 1995.

Russo, Stacy Shotsberger. The Library as Place in California. Jefferson, NC: McFarland \& Company, 2008.

Tetreault, Ronald. "Beneficial Spaces: The Rise of Military Libraries in the British Empire." In The Library as Place: History, Community, and Culture, edited by John E. Buschman and Gloria J. Leckie, 29-39. Westport, CT: Libraries Unlimited, 2007.

\footnotetext{
i In keeping with common practice, passages from the "Convolutes" and "First Sketches" of the Eiland \& McLaughlin English-language edition of The Arcades Project (Benjamin 1999) are cited herein with simply their passage numbers in brackets.
} 